\title{
Model Bimbingan Konseling Berbasis Religiusitas dalam Mengatasi Kesulitan Belajar Siswa
}

\author{
Siti Bahiroh \\ Universitas Muhammadiyah Yogyakarta \\ bahiroh@umy.ac.id \\ Fitriah M. Suud \\ Universitas Muhammadiyah Yogyakarta \\ fitriahmsuud@gmail.com
}

\begin{abstract}
This study aims to explore guidance based on religious counseling, namely through internalization of Islamic values in private schools in Yogyakarta. This qualitative research uses a case study approach. Data collection by observation, interview, and documentation. Participants were 7 counseling guidance teachers, Principal, deputy headmaster, 8 teachers. The results showed that students' problems appeared related to discipline, morals, learning and discipline. The cause is more influenced by the use of gadgets and environmental influences. The religiosity-based counseling model that is applied is to invite students to enter the mosque, to make good habits, to set an example, to help students to be comfortable in learning and to share with students when they are relaxed.
\end{abstract}

Keywords: Counselling guidance, religious, learning difficulties

\begin{abstract}
Abstrak
Penelitian ini bertujuan untuk mengeksplorasi bimbingan konseling berbasis agama, yaitu melalui internalisasi nilai-nilai Islam di sekolah swasta di Yogyakarta. Penelitian kualitatif ini menggunakan pendekatan studi kasus. Pengumpulan data dengan observasi, wawancara, dan dokumentasi. Peserta adalah 7 guru bimbingan konseling, Kepala Sekolah, wakil kepala sekolah, 8 guru. Hasil penelitian menunjukkan bahwa masalah siswa muncul terkait dengan disiplin, moral, pembelajaran dan disiplin. Penyebabnya lebih banyak dipengaruhi oleh penggunaan gadget dan pengaruh lingkungan. Model bimbingan konseling berbasis religiusitas yang diterapkan adalah mengajak siswa masuk ke masjid, pembiasaan
\end{abstract}


melakukan kebaikan, member tauladan, membiat siswa nyaman dalam belajar dan berbaus dengan siswa di saat santai.

.Kata Kunci : Bimbingan Konseling, Religiusitas, Kesulitan Belajar

\section{Pendahuluan}

Penelitian sebelumnya menunjukkan telah terjadi beberapa persoalan kenakalan remaja di sekolah. ${ }^{1}$ Banyak faktor yang menyebabkan kenakalan remaja terjadi. Diantara faktor tersebut adalah kontrol diri yang rendah, hubungan orang tua-anak yang kurang baik, pengaruh teman sebaya, status ekonomi dan budaya. ${ }^{2}$ Para ahli psikologi dan pendidikan menekankan bahwa penyelesaian masalah-masalah yang lazimnya timbul pada masa remaja (15-20 tahun) berdampak cukup besar terhadap kebahagiaan di masa dewasa ${ }^{3}$.Pendidikan merupakan salah-satu lembaga yang dapat memberikan pengaruh besar terhadap perubahan perilaku seorang remaja. Dan salah satu cara yang dapat ditempuh untuk mengatasi kenakalan remaja adalah melalui bimbingan konseling di sekolah.

Pelayanan bimbingan dan konseling di Indonesia ${ }^{4}$ telah tersedia diberbagai lembaga pendidikan sekolah sejak awal tahun 1960-an dan telah berkembang dengan pesat terutama di jenjang pendidikan sekolah menengah. Adanya pelayanan bimbingan dan konseling di sekolah memberikan jaminan semua peserta didik untuk mendapatkan perhatian sebagai sosok pribadi yang sedang berkembang, dan akan mendapat bantuan dalam menghadapi semua tantangan, kesulitan dan masalah yang berkaitan denganperkembangan mereka ${ }^{5}$.Faktor pendorong lain perkembangan konseling di Indonesia adalah adanya kebutuhan nyata para siswa seperti : a) siswa menghadapi masa-masa kritis (kegagalan sekolah, gagal dalam pergaulan, penyalah gunaan obat bius (b) kesulitan dalam pemahaman diri, pengambilan keputusan dalam karir, akademik, pergaulan sosial (c) mencegah kesulitan yang dihadapi dalam pergaulan dan

${ }^{1}$ Lutfia Uli Na'mah et al., "Peningkatan Pengetahuan Melalui Sosialisasi Kesehatan Reproduksi Remaja Tentang Kenakalan Remaja.," Proceeding of The URECOL, January 21, 2019, 263-66, http://repository.urecol.org/index.php/proceeding/article/view/349.

${ }^{2}$ Xue Weng, Mao-Sheng Ran, and Wing Hong Chui, "Juvenile Delinquency in Chinese Adolescents: An Ecological Review of the Literature," Aggression and Violent Behavior 31 (November 1, 2016): 26-36, https://doi.org/10.1016/J.AVB.2016.06.016.

${ }^{3}$ W.S.Winkel and M.M. Sri Hastuti, Bimbingan Dan Konseling Di Institusi Pendidikan (Yogyakarta: Media Abadi, 2013).

${ }^{4}$ Keith Tudor and Brigitte Viljoen, "Counselling and Psychotherapy of and in the South Pacific," Asia Pacific Journal of Counselling and Psychotherapy 9, no. 1 (January 2, 2018): 3-19, https://doi.org/10.1080/21507686.2017.1415944.

${ }^{5}$ W.S.Winkel and Hastuti, Bimbingan Dan Konseling Di Institusi Pendidikan. 
seksual (d) menopang kelancaran dalam pengembangan kemandirian, percaya diri, citra diri, dan lain-lain. ${ }^{6}$

Di Indonesia, sejarah pelayanan bimbingan sebagai usaha profesional, sejak awal dipusatkan di berbagai lembaga pendidikan sekolah, terutama di jenjang pendidikan menengah. Secara formal pelayanan bimbingan ini dimulai awal tahun 1960-an. Kendati demikian, Hallen ${ }^{7}$ menuliskan dalam bukunya Bimbingan dan Konseling, bahwa penggunaan istilah bimbingan dan penyuluhan sebagai terjemah dari guidance and counseling oleh Tatang Mahmud sudah ada sejak tahun 1953, sebagaimana juga yang dikemukakan oleh Tohari Musnamar bahwa Tatang Mahmud, yang saat itu menjabat di Departemen Tenaga kerja Republik Indonesia menyebarkan edaran untuk meminta persetujuan kepada beberapa orang yang dipandang ahli, terkait apakah istilah guidance and counseling itu dapat diterjemahkan "bimbingan dan penyuluhan" 8 pada waktu itu tidak ada yang menolak. Karena pendapat Tatang Mahmud ini tidak ada yang menolak, maka mulai saat itu istilah Bimbingan dan Penyuluhan sebagai terjemah dari guidance and counseling menjadi populer dan tidak ada masalah dengan istilah tersebut.

Dalam perkembangan selanjutnya pada tahun 1970, di awal masa pembangunan Orde Baru, istilah penyuluhan sebagai terjemah dari counseling, yang berkonotasi dengan psychological-counseling, banyak pula dipergunakan dibidang bidang lainnya, misalnya penyuluhan pertanian, penyuluhan KB, penyuluhan Gizi, penyuluhan Hukum, penyuluhan Agama, yang diartikan hanya sebagai penerangan atau informasi, bahkan bentuknya sebatas ceramah dan pemutaran film. Perkembangan pemakaian istilah yang demikian itu, para ahli yang tergabung dalam IPBI (Ikatan Petugas Bimbingan Indonesia), mulai ragu akan ketepatan penggunaan istilah penyuluhan sebagai terjemahan dari counseling. Selanjutnya sebagian dari para ahli berpendapat bahwa sebaiknya istilah penyuluhan itu dikembalikan ke istilah aslinya yakni counseling. Hingga saat ini dikenal dengan istilah "bimbingan dan konseling".

Keberhasilan bimbingan dan konseling di lembaga pendidikan ditentukan banyak faktor, diantaranya kekompakan dari unsur-unsur yang terlibat seperti kepala sekolah, guru bimbingan dan konseling (selanjutnya dengan istilah BK), wali kelas, juga wali siswa. Namun demikian unsur pokok yang bertanggung jawab sepenuhnya adalah guru BK. Pentingnya guru BK dalam menangani permasalahan siswa ini, disamping harus paham mengenai tugas dan pekerjaan sehari-hari di sekolah, ia harus selalu meng up date ilmu

${ }^{6}$ Andi Mappiare, Pengantar Konseling Dan Psikoterapi (Jakarta: Rajawali, 1992).

${ }^{7}$ Hallen, Bimbingan Dan Konseling, (Jakarta: Ciputat Pers, 2002).

${ }^{8}$ Siti Bahiroh, Sekar Ayu Pratiwi, and Fitriah M. Suud, "Improving Student Happiness Through The Snowball Throwing Method In The Implementation of Student Conceling Groups of State Vocational Schools 2 Depok Yogyakarta," Journal of Critical Reviews 7, no. 5 (2020): 563-68, https://doi.org/doi: 10.31838/jcr.07.05.117. 
pengetahuan yang berkait dengan tugasnya selaku konselor di sekolah. ${ }^{9}$ Kendati secara teoritik teknik konseling itu telah diuraikan dalam buku-buku, namun secara implementasi selalu terjadi pengembangan yang sesuai dengan tantangan yang dihadapi di masyarakat dan lingkungan pendidikan, kondisi dan situasi konseli (siswa) dan permasalahan yang dihadapinya.Hal ini digambarkan oleh Bimo Walgito dalam buku "Bimbingan dan Penyuluban di Sekolab", bahwa sebagai salah satu cabang ilmu sosial, bimbingan dan penyuluhan mempunyai sifat ketergantungan pada situasi sosial setempat ${ }^{10}$.

Dalam buku Counseling in School yang dikutip W.S. Winkel \& M.M. Sri Hastuti, Schmidt menekankan bahwa alasan pokok adanya konselor di sekolah adalah untuk mendampingi siswa agar berkembang menjadi orang yang lebih mampu dan lebih manusiawi, dalam arti menjadi pelajar yang lebih baik, menjadi warga sekolah yang setia, dan warga masyarakat yang lebih berguna ${ }^{11}$. Pendampingan siswa penting mengingat kondisi dan situasi zaman yang selalu berubah terus menerus, pada sisi lain para siswa mengalami adanya masa-masa kritis dalam masa perkembangannya, terutama pada masa remaja. Dengan demikian konseling merupakan sebuah kebutuhan yang urgen di sekolah.

Di Indonesia selain sekolah-sekolah negeri (pemerintah), banyak juga sekolah swastadansekolah-sekolahberbasis Islam. Menurut Azyumardi Azra, pendidikan Islam memiliki karakter khusus, antara lain penekanan dalam pendidikan Islam ditujukan pada pencarian ilmu pengetahuan, penguasaan dan pengembangannya didasarkan atas ibadah kepada Allah SWT. Pencarian, penguasaan dan pengembangan ilmu pengetahuan ini merupakan proses yang berkesinambungan dan pada prinsipnya berlangsung seumur hidup (long life education), dalam sistem pendidikan modern. ${ }^{12}$ Selanjutnya pengakuan akan potensi dan kemampuan seseorang untuk berkembang dalam suatu kepribadian, artinya setiap pencari ilmu adalah makhluk Allah yang perlu dihormati dan disantuni, agar potensi yang dimilikinya dapat teraktualisasikan dengan baik. Uraian tersebut menunjukkan bahwa para siswa di sekolah berbasis Islam diharapkan memiliki sifat religius yang kuat, sehingga persepsi dan konsepsi hidupnya sangat dipengaruhi oleh ajaran agamanya. ${ }^{13}$ Dengan demikian penerapan konseling Islami disekolahtersebut akan lebih efektif.

${ }^{9}$ Masoumeh Alavi, Nazanin Boujarian, and Mohd Tajudin Ninggal, "The Challenges of High School Counselors in Work Place," Procedia - Social and Behavioral Sciences 46 (January 1, 2012): 4786-92, https://doi.org/10.1016/J.SBSPRO.2012.06.335.

${ }^{10}$ Bimo Walgito, Bimbingan Dan Penyuluban Di Sekolah (Yogyakarta, 1995).

${ }^{11} \mathrm{~W} . S$. Winkel and Hastuti, Bimbingan Dan Konseling Di Institusi Pendidikan.

${ }^{12} \mathrm{O} . Y u$ Burov, Life-Long Learning: Individual Abilities versus Environment and Means, CEUR Workshop Proceedings, 2016, http://lib.iitta.gov.ua/704844/.

${ }^{13} \mathrm{~T}$ Musnamar, Dasar-Dasar Konseptual Bimbingan Dan Konseling Islami (Yogyakarta: UUI Pres, 1992). 
Penelitian ini merupakan penelitian kualitatif, menggunakan pendekatan studi kasus. Sumberdatanya terdiri dari 7 guru bimbingan konseling, Kepala Sekolah, wakil kepala sekolah, 8 guru dan siswa kelas X. Penelitian ini akan menguraikan kenakalan remaja yang terjadi di sekolah swasta X di Yogyakarta dan apa faktor yang menyebabkan kenakalan remaja bisa terjadi disana. Sebagai sekolah yang berbasis Islam tentunya penangganan kenakalan remaja akan diselesaikan dengan pendekatan yang lebih religius. Oleh sebab itu lebih lanjut penelitian ini akan melihat bagaimana kenakalan remaja yang muncul diselesaikan melalui bimbingan konselingberbasisreligius, bagaimana kelebihan dan kelemahan yang dimiliki dengan pendekatan ini akan diuraikan secara rinci.Jenis penelitian ini adalah kualitatif dengan pendekatan fenomenologi. Strategi samplingnya menggunakan purposive sampling. Subyek utama dalam penelitian ini adalah guru bimbingan dan konseling, kepala sekolah, wakil kepala sekolah bidang kesiswaan, wali kelas, siswa, dan guru mata pelajaran.

Data penelitian ini dikumpulkan melalui observasi, wawancara dan dokumentasi. Observasi dilakukan sebelum menyusun proposal penelitian dan selama penelitian. Beberapa hal yang telah diobservasi adalah kantor dan ruangan fasilitas BK, kegiatan konseling, kegiatan guru BK dari pagi hinggasiang, dan pelaksanaan shalat jama'ah, dan lain-lain. Wawancara mendalam dilakukan dengan para informan yaitu melalui wawancara terstruktur dan wawancara terbuka. Sementara dokumen dikumpulkan dalam bentuk tertulis maupun dokumen dalam bentuk rekaman. Analisa data dilakukan dengan metode diskriptif analitik. Data data yang diperoleh di lapangan terlebih dahulu di kelompokkan berdasarkan kualitas dan kategorinya. Selanjutnya data dianalisis dan diinterpretasikan dengan menggunakan pola berfikir induktif dan deduktif. Untuk menganalisis internalisasi nilai nilai Islam dalam proses bimbingan dan konseling, peneliti menggunakan pendekatan semiotik

\section{Hasil dan Pembahasan}

\section{Masalah belajar siswa}

Masalah belajar merupakan bagian dari kegiatan terprogram pengembangan diri siswa. Layanan bimbingan dan konseling bidang belajar ini bertujuan untuk membantu siswa mengembangkan kemampuan belajar dalam rangka mengikuti pendidikan sekolah dan belajar secara mandiri agar mencapai prestasi(data dokumentasi;2019).Permasalahan utama yang dihadapi siswa siswi SMA X terkait dengan bidang belajar ini adalah kesulitan belajar. hal ini nampak jelas dilihat dari hasil capaian prestasi belajar, motivasi belajar rendah, yang ditunjukkan dengan perilaku seperti : masuk kelas menunggu perintah padahal bel telah berbunyi, sulit mengatur waktu, fenomena di kelas ketika proses belajar mengajar berlangsung, ada siswa di dalam kelas tidur, ada juga yang main game menggunakan HP, sering tidak masuk sekolah, sampai bolos dari sekolah 
(interview mg). Rozi salah seorang siswa kelas X mengatakan bahwa saya belajar kalau mau ujian.Meskipun hanya dua atau tiga siswa di kelas yang mengalami kesulitan belajar ini, namun jika tidak ditangani secara baik akan mengganggu konsentrasi belajar siswa lainnya.

Masalah kedisiplinan ini terkait dengan pelanggaran tata tertib sekolah, misal : siswa harus shalat dhuha, shalat jama'ah, datang tepat waktu, berseragam, rambut rapi, dan lain lain. Pelanggaran tata tertib ini setiap hari pasti ada, hal ini bisa langsung terdeteksi karena guru BK setiap hari ada digerbang masuk, ikut menyambut datangnya siswa bersama kepala sekolah dan beberapa guru yang mengajar pagi. Bagi siswa yang melanggar kedisiplinan dipanggil guru BK untuk dikonseling. Untuk keterlambatan, siswa tetap boleh masuk atas ijin guru BK. Dari hasil pengamatan, siswa siswi yang melakukan pelanggaran tata tertib itu ajeg (anaknya itu terus) dan hanya satu dua yang memang terlambat karena ada halangan.

Kasus lain seperti shalat, juga masih ada siswa yang sulit melakukannya. Ketika masuk waktu shalat dia keluar tapi ngumpet, atau keluar gedung dengan naik pagar. Menurut Pak Mugi, tugas lapangan bagi guru BK ini yang sangat sulit, guru harus mencari siswa, kadang kadang harus berbaur untuk nongkrong saat istirahat, sambil mengawasi beberapa siswa yang sering melakukan pelanggaran. Ketika ditanyakan siswa keluar saat istirahat dengan lompat pagar, apa yang dilakukan ? di luar mereka jajan sambil merokok, karena di dalam lingkungan sekolah tak boleh merokok. Pak Mugi yang sudah dua puluh tahun lebih bertugas di SMA X, mengatakan bahwa perubahan perilaku siswa yang drastis ini sejak adanya Hp, yang dulu tidak seperti itu. Terkait dengan sopan santun siswa SMA X ada dua tiga anak yang masih kurang, hal ini dirasakan saat berlangsungnya wawancara, ada beberapa siswa yang juga datang dan mengajak bicara dengan guru BK, yang mestinya siswa itu paham kalau sedang ada tamu.

Pergaulan antar teman sebaya merupakan hal yang wajar terjadi di sekolah, namun dalam pergaulan tersebut sering memunculkan masalah, seperti masalah membuli teman. Di SMA X, kasus buli ini masih ada, tetapi dalam batas kewajaran seperti memanggil dengan nama samaran, minta dibayarin saat jajan dan lain lain. Kasus lain seperti pacaran, tetap ada namun dilingkungan sekolah tetap dalam pengawasan guru. Untuk berkelahi semenjak ada kasus siswa berkelahi sampai masuk rumah sakit, karena ada retak di rahang beberapa tahun lalu, saat ini tidak ada lagi. Untuk pelanggaran berat seperti narkoba, siswa SMA X tidak ada yang terlibat.

Kebanyakan para siswa siswi kurang mengerti tentang bagaimana cara mengisi waktu luang. Mereka banyak menggunakan waktu hanya untuk bermain Hp ketika sedang tidak mengikuti pelajaran, seperti saat istirahat, atau ada jam pelajaran tertunda. Namun demikian, ada juga siswa yang memiliki hobi olah raga, mereka memanfaatkan untuk sepak bola, voli, silat, sebagaimana dikatakan 
salah seorang siswa ketika ditanya tentang bagaimana jika kebetulan guru mata pelajaran tidak bisa hadir, beberapa siswa menjawab bahwa : mereka punya club basket, voli, sehingga langsung ke lapangan bermain bola. Ada juga yang ke ruang BK bertanya tentang studi lanjut. Terkait dengan penggunaan waktu luang ini, guru BK mengeluhkan, bahwa semenjak ada Hp, mereka susah sekali mengendalikan siswa.

Siswa siswi SMA X mengalami masalah pergulatan dalam diri sendiri, terutama terkait dengan kegelisahan tentang masa depan. Menurut ibu Hana banyak anak anak itu datang ke BK tanpa dipanggil, mereka menyatakan keinginannya untuk melanjutkan studi di Perguruan Tinggi yang bagus, namun tidak didukung dengan semangat belajar yang tinggi (interview Hn). Ibu Hana juga menjelaskan bahwa ada juga siswa siswi yang berkonsultasi melalui whatsapp, sehingga bisa dilakukan juga dirumah dan dimanapun berada. Masalah masalah yang terkait dengan informasi untuk kepentingan siswa, dan masalah pribadi yang tidak mungkin disampaikan langsung mereka bisa melalui WA.

\section{Faktor-faktor Penyebab Munculnya Permasalahan Siswa}

Pada umumnya anak anak yang bermasalah, mereka berasal dari keluarga yang jarang berinteraksi dengan sesama anggota keluarga. Kedua Orang tua mereka semua bekerja, saudaranya juga masing masing sibuk dengan urusan rumah tangganya, sehingga orang tua jarang ketemu dengan anaknya kecuali pada sore sampai malam hari. Kondisi yang sudah lelah ini tidak mungkin orang tua akan menanyakan tentang sekolah anak-anaknya. Senada itu, pak Mugi mengakatan anak anak di SMA X juga berasal dari orang tua yang broken, mereka kurang kasih sayang dari orang tua, sehingga menjadi anak yang ngeyel (tidak nurut).

Terkait dengan permasalahan kedisiplinan anak dalam mengikuti shalat jama'ah, memang beberapa siswa siswi yang malas, sehingga bapak dan ibu guru BK harus selalu mengontrol mengingatkan. Ketika dirunut lebih jauh menurut bapak Rusbani, memang basis agama keluarga berpengaruh, berikut penuturan beliau :

"ya..bagaimana lagi orang tua murid belum menjalankan shalat lima waktu, tetapi alhamdulillah sebagian besar anak anak disini mau menjalankan shalat, mengaji, karena dibiasakan terus menerus"(interview $\mathrm{Rb}$ )

Meskipun secara materi anak itu tercukupi kebutuhannya, pergi ke sekolah dengan kenderaan bagus, HP yang mahal, namun jika dibesarkan dalam keluarga yang tidak harmonis, maka akan muncul bentuk protes yang berbeda beda antara satu dengan lainnya.

\section{Model-model dan Pola Pelaksanaan Bimbingan dan Konseling}

Menurut dua guru BK di SMA X, tugas yang dilaksanakan mencakup banyak hal yang berkait dengan kedisiplinan siswa, seperti siswa terlambat 
masuk, siswa tidak berseragam, siswa malas masuk kelas, membolos, siswa malas shalat berjama'ah, tidak membayar SPP, tidak masuk sekolah berhari hari, dan lain lain. Selain itu ada berbagai pelayanan yang diberikan kepada siswa, seperti pelayanan informasi, pelayanan problem individual siswa. Menurut ibu Hana, setiap hari pasti ada yang datang untuk menanyakan hal hal yang terkait dengan perencanaan studi lanjut. Bahkan jika banyak yang antri bimbingan, bu Hana bersedia bimbingan melalui WA. Pak Mugi juga menjelaskan bahwa, anak anak itu lebih menurut dengan guru BK meskipun tidak memberikan nilai, karena memang tidak mengajar mata pelajaran tertentu.

Dari wawancara dengan dua guru BK SMA X tersebut menunjukkan bahwa guru BK merupakan figur yang dibutuhkan siswa, hal ini disebabkan keberadaan guru BK di sekolah mulai pagi sampai selesai proses belajar mengajar, bahkan dipastikan sampai semua siswa tidak berada di sekolah. Sekolah swasta termasuk SMA X ini, guru mata pelajaran hanya hadir saat ada jam mengajar saja.Jika ditelaah lebih lanjut ada perbedaan dengan guru di sekolah negeri yang terikat dengan ketentuan administrasi sekolah, mereka harus berada di sekolah dari pagi sampai selesai, sesuai jam kantor. Di sekolah negeri para siswa ada kesempatan untuk berinteraksi dengan guru mata pelajaran, di luar kelas, bahkan bisa bertanya pelajaran yang telah diberikan di kelas. Di sekolah swasta, guru BK menjadi sosok figur yang selalu ada untuk siswa, sehingga menjadi tumpuan mencurahkan segala masalah yang dialami siswa.

Beberapa uraian sebelumnya menggambarkan bahwa, SMA X yang jumlah siswanya tiga ratus tiga puluh sembilan, dengan dua guru BK, maka pelaksanaan BK tidak mungkin menjangkau secara menyeluruh, sehingga beberapa layanan terkait dengan pembinaan kepribadian siswa, bakat minat siswa, dan beberapa masalah belajar, harus dikerjasamakan dengan guru, wali kelas dan bidang kesiswaan. Selain itu juga uraian tentang tugas tugas guru BK dengan peran yang senyatanya dilaksanakan, keberadaan guru BK di sekolah, dan kedekatan siswa dengan guru BK. Jika ditinjau dari model modelbimbingan dan konseling, SMA X menggunakan model Kenneth B. Hoyt. Kendati demikian tidak sama persis apa yang didiskripsikan Hoyt, karena memang latar belakang sosiologis dan pemikiran tentang hakekat pendidikan berbeda, antara sekolah di Amerika Serikat dan sekolah di Indonesia yang berbasis Islam. Ada pengembangan dalam fungsi pengentasan (kuratif), yang tidak ada di sekolah lain, yakni bimbingan dengan model "anak asuh dalam bimbingan". Hal ini diterapkan dan menunjukkan peningkatan keberhasilanya.Di SMA X, dalam hal pelayanan bimbingan, sama dengan Hoyt, yakni bimbingan terintegrasi pada tujuan tujuan institusional, kurikuler, dan instruksional. Guru BK memiliki keahlian sebagaimana konselor sekolah yakni sebagai sumber tenaga pendidik, memiliki keahlian khusus yang tidak dimiliki tenaga tenaga pendidik lain. 


\section{Strategi Internalisasi Nilai Islam dalam Proses Konseling}

Sebagai sekolahberbasis Islam, sekolah $\mathrm{X}$ tentu berupaya mewujudkan sekolah terdepan, dengan peserta didik yang berkepribadian Islami dan berprestasi. Namun demikian untuk mewujudkan siswa berkepribadian Islami tidaklah mudah dan cepat, tetapi melalui proses yang panjang dan berbagai lini ditempuh, seperti pendidikan agama, pembentukan organisasi, kegiatan ekstra, dan lain lain. Bimbingan dan konseling merupakan sebuah layanan yang disediakan sekolah untuk memberikan bantuan berupa pelayanan bimbingan kepada setiap siswa dalam mengembangkan dirinya. Pengembangan diri di SMA $\mathrm{X}$ adalah pengembangan secara totalitas yang mencakup empat dimensi yakni ; dimensi fisik- biologis, dimensi mental-psikis, dimensi sosio-kultural, dan dimensi spiritual (rohani) ${ }^{14}$. Selanjutnya, pentingnya konseling spiritual dilukiskan Sunaryo Kartadinata dalam buku "Menguak Tabir Bimbingan dan Konseling sebagai upaya Pedagogis" bahwa keterkaitan masalah spritual dengan bimbingan perlu dikembangkan. Bimbingan sebagai proses membantu individu memahami diri dan dunianya yang dalam konteks pendidikan bimbingan terfokus pada pengembangan lingkungan belajar yang dapat memfasilitasi individu memperoleh kesuksesan belajar. Tujuan pendidikan adalah meningkatkan kualitas manusia yang bercirikan takwa, maka bimbingan dan konseling tidaklah cukup menggunakan kaidah psikologis dan sosiokultural saja, tetapi harus mampu menangkap eksistensi manusia sebagai makhluk Allah swt.

Di sekolah berbasis Islam, termasukSMA X, para guru BK dan guru mata pelajaran telah mengaitkan masalah spiritual ini melalui proses bimbingan dan konseling. Para guru telah dibekali pendidikan agama melalui kegiatan pengajian, baitul arqom, dan kegiatan lainnya yang diselenggarakan oleh Pimpinan Yayasan. Dengan bekal pengetahuan agama tersebut para guru diharapkan dapat memanfaatkan baik untuk dirinya maupun dalam rangka mendukung tugas tugas pekerjaannya. Berikut ini paparan bu Katini : "saya itu guru negeri yang ditugaskan di sekolah $\mathrm{X}$ ini, jadi harus tunduk dan patuh pada aturan yayasan. Sebagai guru disini harus mengikuti kegiatan ke-Islaman. Denganbegitu kita dapat ilmu agama, terus bisa kita tularkan ke siswa melalui konseling, seperti mengajak mereka untuk kebaikan, disiplin, cinta sesama, jujur, dan lainnya" (interview Kt).

Berikut beberapa cara yang telah digunakan guru BK untuk memasukkan atau menginternalisasikan nilai nilai Islam dalam proses konseling: a) Mengajak siswa yang terlambat datang ke sekolah untuk masuk ke Masjid b) Pembiasaan c) Memberi tauladan d) Membuat siswa bahagia, nyaman e) Berbaur dengan siswa-siswi disaat santai f) Berempati g) Berusaha untuk selalu ada di sekolah.

${ }^{14}$ Hanna Djumhana Bastaman, Integrasi Psikologi Dengan Islam Menuju Psikologi Islami (Yogyakarta: Pustaka Pelajar, 2005). 


\section{Mengajak siswa terlambat masuk untuk ke Masjid}

Sebagaimana telah diuraikan, bahwa semua guru BK di SMA X inisetiap pagi hadir menyambut kedatangan siswa bersama manajemen Sekolah. Guru BK bisa bersalaman langsung dan menatap wajah setiap anak bimbingannya, sehingga secara fisik anak anak termonitor setiap hari. Selanjutnya bagi yang datang terlambat, oleh guru BK langsung diajak ke Masjid, karena memang tidak diperkenankan masuk kelas untuk jam pertama pelajaran. Di Masjid inilah guru BK memberikan konseling atau bimbingan kelompok. Siswa diajak shalat dhuha, dengan keyakinan bahwa ibadah kepada Allah mempunyai peranan yang menakjubkan dalam diri seorang anak. Dengan cara inilah sebenarnya upaya guru memupuk "Fitrah Iman" para siswanya, dengan harapan bisa diaktualisasikan menuju kecenderungan berperilaku positif. Selain itu, ibadah dapat meredam pemberontakan jiwa anak, amarah dan nafsu syahwat serta meningkatkan kekhusyukan.

\section{Pembiasaan}

Pembiasaan merupakan cara mendidik yang sudah ada sejak jaman Nabi. Dalam psikologi perilaku, upaya rekayasa dan kondisi lingkungan luar adalah hal yang mempengaruhi kepribadian manusia. Di lingkungan sekolah khususnya di SMA X ini, siswa dibiasakan untuk beragama dengan tertib. Dibawah pengawasan guru BK secara langsung siswa dibiasakan melakukan shalat berjama'ah di Masjid. Dengan shalat berjama'ah ini, ada banyak kemanfaatan yang bisa diambilyaitu dapat melatih disiplin siswa, membangun interaksi positif, dan menambah kecintaan dan kelekatan siswa dengan masjid sebagai rumah Allah. Menurut ibu Nanik Hariyati, dengan dibiasakan shalat diharapkan dapat membentuk akhlak kepada Allah. Tuturnya,begini bu jika disiplin shalat bisa ditegakkan, maka secara otomatis iman dan takwa itu terpatri di hati siswa. dengan iman yang kuat, meyakinkan siswa itu tidak sulit dan mudah dibuka kesadarannya (interview $\mathrm{Nn}$ ).

\section{Memberi tauladan}

Dalam sebuah ayat al-Qur'an, yaitusurat al-Ahzabayat 21 dijelaskan bahwa Rasul adalah uswah hasanah atau teladan bagi umat Islam, "Laqad kana lakum fii Rasulillahi Uswatun hasanah". Dalam hal ini karena guru BK itu akan melaksanakan tugas membimbing, maka harus lebih dahulu membimbing dirinya sendiri. Menurut bu Katini selaku koordinator guru BK di SMA X, dengan bahasa Jawanya yang khas menuturkan bahwa: "masalah budi pekerti atau akhlak ini sangat penting untuk guru apalagi guru BK yang menjadi contoh siswa, jadi sebagai koordinator guru BK tetap saja mengingatkan kolega guru BK supaya menjaga sopan santun" (interview Kt)". Di SMA X ini, guru BK memberikan keteladanan dalam bentuk : Pertama, disiplin dalam bertugas, artinya setiap guru BK selalu berada di sekolah dari jam 06.30-15.30, secara otomatis pelayanan untuk siswa bisa bejalan lancar, "sebagai guru BK kita harus 
berangkat gasik (lebihawal, pen.) dan pulang akhir sendiri sampai siswa siswi habis pada pulang semua" (interview $\mathrm{Sw}$ ).

Kedua, keteladanan dalam berinteraksi dengan sesama guru dan siswa. Rata rata guru BK mudah bergaul dengan sesama guru, siswa bahkan dengan tenaga karyawan. Hubungan baik yang dijalin guru BK dengan siswa ini penulis lihat saat observasi, ada alumni yang datang ke ruang BK. Alumni tersebut telah bekerja di sebuah perusahaan ternama. Ada kata kata dari alumni tersebut"saya dulu bandel pak, tapi kalau tidak dijewer ya saya gak bisa jadi seperti sekarang ini pak" (interview Wk).Dialog tersebut menunjukkan bahwa ada hubungan baik antara siswa dengan guru BK, dan menunjukkan rasa terimakasih atas bimbingan guru BK. Selain itu para guru BK kompak dan saling membantu.

\section{Membuat siswa bahagia dan nyaman}

Kebutuhan anak muda terutama di usia 16-19 tahun adalah kebutuhan yang bersifat psikologis. Mereka sangat membutuhkan dukungan, perhatian dalam setiap langkah yang diperbuat, dan pengakuan pada alam pikirannya. Mereka ingin mengatur kehidupannya sendiri, memperoleh prestasi, menjalin persahabatan dengan teman sejenis dan lawan jenisnya.Kebutuhan yang bersifat psikologis ini, jika tidak terpenuhi mereka akan frustasi dan malas belajar. Menurut keterangan beberapa guru BK, memang kebanyakan siswa yang sengaja menemui guru BK rata rata mereka butuh pemantapan, dukungan atas keputusan yang diambil dalam banyak hal, baik terkait dengan masalah masalah sekolah maupun masalah sosial. Dalam suasana seperti ini guru BK sangat dibutuhkan, sehingga bisa memanfaatkan waktu wawancara dengan siswa seefektif mungkin. Menurut keterangan Rusbani membimbing itu harus dengan rasa kasih sayang, sehingga ketika kita memasukkan nilai nilai Islam, anak bisa memahaminya, menghubungkannya dengan problem yang dialaminya, selanjutnya mengakhiri bimbingan itu dengan rasa lega, senang, karena beban berkurang.

\section{Berbaur dengan siswa siswi disaat santai}

Guru BK memegang peranan yang penting dan dibutuhkan, namun demikian sebagai manusia biasa, mereka mempunyai keterbatasan. Dalam memahami siswa, guru BK mempunyai keterbatasan, misalnya bagaimana memahami potensi siswa, masa depan siswa dan lain lain. Untuk mengetahui potensi individu lazim menggunakan alat tes, meskipun dengan alat tersebut belum menjamin kebenarannya secara pasti. Cara lain yang digunakan guru BK adalah berbaur dengan siswa, "kami guru BK ini bisa dibilang tak pernah nganggur, saat siswa masuk pelajaran, kita mengerjakan administrasi. Kemudian saat istirahat kita semua wajib keluar ruangan untuk berbaur dengan siswa, kita ikut percakapan mereka yang berkelompok. Jika ada yang murung, kelihatan sedih, kita dekati pelan pelan dengan penuh empati" (interview Rb). Uraian tersebut menunjukkan bahwa dengan berbaur bersama-sama para siswa, guru 
BK berharap agar tahu apa yang sebenarnya yang lagi dibutuhkan, sehingga bisa membantu siswa bimbingannya.Uraian tersebut dapat disimpulkan bahwa guru BK dituntut untuk bisa memerankan diri sebagai orang tua, bahkan sebagai teman, saat berbaur itulah kesempatan memasukkan nilai akhlak pada siswa.

Terkait dengan strategi internalisasi nilai-nilai Islam ini, untuk guru mata pelajaran, semua guru berupaya menyisipkan nilai nilai Islam saat mentransfer ilmu pengetahuan, misalnya ibu Murni guru bahasa Indonesia mengatakan : pentingnya bahasa dikaitkan dengan "pengalaman Nabi dalam mendakwahi ratu Bilqis" untaian bahasa yang ditulis Nabi sebagai ajakan memeluk agama Islam. guru matematika, mengaitkan pentingnya pelajaran ini dengan ilmu falak, untuk mengetahui awal bulan. Untuk berdo'a sebelum dan sesudah di sekolah X iniwajib dilaksanakan, bahkan tadarus al-Qur'an di pagi hari juga diwajibkan.

Penelitian ini menemukan permasalahan yang pada umumnya terjadi pada remaja. ${ }^{15}$ Masalah belajar merupakan masalah utama yang dialami seorang siswa. Terkait dengan masalah kesulitan belajar ini, Muhibbin Syah 16, menguraikan tentang dua faktor penyebab kesulitan belajar : pertama faktor intern siswa, adalah hal atau kondisi, keadaan yang timbul dari dalam siswa, seperti rendahnya kapasitas intelegensi, labilnya emosi dan sikap, gangguan psikomotor seperti gangguan alat indera. Kedua, faktor ekstern siswa, yakni kondisi atau keadaan yang datang dari luar diri siswa, mencakup : lingkungan keluarga, lingkungan masyarakat, dan lingkungan sekolah.Persoalan dalam penelitian ini menjadi lebih rumit karena dipengaruhi oleh orangtua, lingkungan belajar dan teman-teman yang mendukung terjadinya permasalahan dalam belajar. Adanya kebebasan penggunaan gadget juga sangat berpengaruh terhadap siswa. ${ }^{17}$ Kendati pun ada dampak positifnya seperti mencari informasi tentang materi pelajaran, namun dampak negatifnya bisa membahayakan anak. Dampak negatif dari gadget, anak menjadi pemalas dan lupa waktu.

Persoalan kedisiplinan sebenarnya juga masih memiliki keterkaitan dengan masalah belajar. Banyak siswa yang terjebak pada prokrastinasi yaitu kebiasaan menunda-nunda pekerjaan mereka. ${ }^{18}$ Selain itu kedisiplinan siswa juga terkait dengan waktu yang tepat untuk mereka hadir ke sekolah dan melaksanakan berbagai rutinitas pembelajaran sesuai dengan waktu yang telah

${ }^{15}$ Nabamita Dutta, Dipparna Jana, and Saibal Kar, "Does State-Level per Capita Income Affect Juvenile Delinquency? An Empirical Analysis for Indian States," Economic Modelling, July 19, 2019, https://doi.org/10.1016/J.ECONMOD.2019.07.011.

${ }^{16}$ Muhibbin Syah, Psikologi Pendidikan Dengan Pendekatan Baru (Bandung: Remaja Rosdakarya, 2016).

${ }^{17}$ Isnanita Noviya Andriyani et al., "Gadgets Playing Behavior of Students In Indonesia," Humanities \& Social Sciences Reviews 8, no. 1 (2020): 264-71.

${ }^{18}$ Jason Wessel, Graham L. Bradley, and Michelle Hood, "Comparing Effects of Active and Passive Procrastination: A Field Study of Behavioral Delay," Personality and Individual Differences 139 (March 1, 2019): 152-57, https://doi.org/10.1016/J.PAID.2018.11.020. 
ditentukan. Dalam kaitannya dengan perilaku remaja ini, Winkel menjelaskan bahwa, tantangan utama pada siswa remaja adalah hal yang terkait dengan pembentukan diri dan internalisasi nilai-nilai dasar kehidupan yang harus diperjuangkan. Selanjutnya dijelaskan pula bahwa jika ada siswa remaja yang sering memprotes tata nilai tradisional, itu bukanlah gejala negatif, tetapi dibantu untuk memperjelas tata nilai tersebut. ${ }^{19}$ Seperti itulah sebenarnya tugas guru BK untuk membantu siswa memahami diri dan lingkungan, menuju pembentukan tujuan dan nilai di masa yang akan datang. Dengan demikian layanan bimbingan pada siswa siswi usia remaja bukanlah hal yang mudah dilakukan, sehingga guru BK dituntut memiliki kreativitas dan seni dalam membimbing.

Hoyt mendiskripsikan model bimbingan yang mencakup sejumlah kegiatan dalam rangka melayani kebutuhan siswa pada jenjang pendidikan dasar dan menengah. ${ }^{20}$ Model ini menekankan pola bimbingan, bahwa seluruh tenaga pendidik berpartisipasi dalam pelaksanaan program bimbingan, konselor sekolah memikul tanggung jawab utama atas perencanaan dan pelaksanaan program bimbingan, yang tidak hanya layanan konseling saja. Oleh karenanya bimbingan pelayananbimbingan dianggap hanya akan berhasil jika tujuan pelayanan bimbingan terintegrasikan pada tujuan tujuan institusional, kurikuler, dan instruksional.

Internalisasi nilai nilai Islam di SMA X, wajib dilakukan oleh semua pendidik. Khoiruddin Bashori, ${ }^{21}$ mengatakanbahwa ada keterkaitan antara perkembangan perilaku prososial dengan penalaran moral siswa. internalisasi merupakan konsep kunci untuk memahami perkembangan moral siswa, semula perkembangan perilaku itu dikendalikan faktor eksternal, adanya internalisasi nilai nilai prososial maka perilaku itu bisa dikendalikan secara internal. Hal penting lainnya yangmenjadi tanggungjawab pendidik di sekolah adalah membiasakan siswa untuk jujur ${ }^{22}$ karena dengan mereka terbuka, orangtua dan guru dapat mengetahui permasalahanya dan mencari jalan penyelesaiannya.

Meminjam teori tersebut, Hal yang sama juga bisa berlaku bahwa, dalam kasus SMA X ini, melakukan internalisasi nilai nilai agama Islam, memiliki harapan perilaku para siswa yang semula dikendalikan faktor eksternal, maka adanya internalisasi nilai nilai Islam yang dilakukan oleh para pendidik termasuk guru BK, perilaku siswa bisa dikendalikan secara internal. Selain peran guru BK

${ }^{19}$ W.S.Winkel and Hastuti, Bimbingan Dan Konseling Di Institusi Pendidikan.

${ }^{20}$ KENNETH B. HOYT, "GUIDANCE: A Constellation of Services," The Personnel and Guidance Journal 40, no. 8 (April 1, 1962): 690-97, https://doi.org/10.1002/j.21644918.1962.tb02185.x.

${ }^{21}$ Khoiruddin Bashori, "Menyemai Perilaku Prososial Di Sekolah," Sukma: Jurnal Pendidikan 1, no. 1 (2017): 57-92.

${ }^{22}$ Fitriah M. Suud, Abd. Madjid, and Sutrisno, "The Study Of Educational Honesty Stages Implementation in an Indonesian School," Humanities \& Social Sciences Reviens 7, no. 4 (2019): 502-10, https://doi.org/https://doi.org/10.18510/hssr.2019.7467. 
sosok kepemimpinan juga memiliki arti penting dalam membentuk prilaku siswa di sebuah sekolah ${ }^{23}$. Melalui perhatian pimpinan dan guru nilai-nilai Islam dapat diinternalisasikan kepada para siswa. Ketika siswa dibiasakan dengan nilai nilai internal Islam, maka akan memiliki nilai nilai internalyang kuat dari internalisasi di sekolah. Selanjutnya para siswa diharapkan tidak terpengaruh pada situasisituasi eksternal dan lebih percaya dengan standar internal perilakunya sendiri. Pelaksanaan internalisasi nilai nilai Islam kedekatan hubungan antara guru dan siswa memiliki peran penting.

Seorang klien dengan pemahaman religiusitasnya dapat menjadi sebuah kontribusi besar dalam fungsi perkembangannya, secara body, mind, dan spirit, dan secara preventif dapat mencegah penyakit seseorang. ${ }^{24}$ Di sekolah $\mathrm{X}$ ini aktifitas keberagamaan memang selalu dipupuk, karena aktivitas keberagamaan merupakan bagian dari reorientasi diri siswa yang harus dilakukan oleh guru BK. Ajaran Islam menjelaskan bahwa bimbingan itu bagian dari bentuk bantuan dan pertolongan kepada sesama manusia dan tanggung jawab semua manusia, kaum muslimin diperintahkan untuk saling membantu, saling menolong untuk kebaikan dan takwa. Seorang konselor yang beragama Islam ${ }^{25}$, termasuk guru BK memiliki spirit beragama yang tinggi sehingga diharapkan dapat melahirkan perbuatan atau perilaku ihsan.

Penanganan persoalan remaja dalam penelitian ini terlihat menggunakan model yang dikembangkan Kenneth B.Hoyt ${ }^{26}$, dan mengambil pola bimbingan spesialis, pendidikan guru BK sesuai yakni S1 BK, guru BK tidak mengajar mata pelajaran, guru BK bekerja mulai dari mengamati siswa secara langsung, mengidentifikasi masalah-masalah siswa dan memberikan layanan. Pola umum bimbingan dan konseling di sekolah yang juga dinamakan "BK Pola 17", artinya ada tujuh belas butir pokok yang menjadi perhatian sekolah dalam penyelenggaraan bimbingan dan konseling ${ }^{27}$. Penyelenggaraan kegiatan

${ }^{23}$ Fitriah M. Suud, "Kepemimpinan Transformasional Dan Implikasinya Pada Pembentukan Budaya Jujur Di Sekolah," Sukma: Jurnal Pendidikan 2, no. 2 (December 10, 2018): 261-86, https://doi.org/10.32533/02206.2018.

${ }^{24}$ D. RUSSELL BISHOP, "Religious Values as Cross-Cultural Issues in Counseling," Counseling and Values 36, no. 3 (April 1, 1992): 179-91, https://doi.org/10.1002/j.2161007X.1992.tb00786.x.

${ }^{25}$ Ameera Balobaid, Alya Qari, and Hamad Al-Zaidan, “Genetic Counselors' Scope of Practice and Challenges in Genetic Counseling Services in Saudi Arabia," International Journal of Pediatrics and Adolescent Medicine 3, no. 1 (March 1, 2016): 1-6, https://doi.org/10.1016/J.IJPAM.2015.12.002.

${ }^{26}$ KENNETH B. HOYT, "What the School Has a Right to Expect of Its Counselor," The Personnel and Guidance Journal 40, no. 2 (October 1, 1961): 129-33, https://doi.org/10.1002/j.2164-4918.1961.tb02413.x.

${ }^{27}$ Miriam A. Carroll-Alfano, "Education, Counseling, Support Groups, and Provider Knowledge of Total Laryngectomy: The Patient's Perspective," Journal of Communication Disorders 82 (November 1, 2019): 105938, https://doi.org/10.1016/J.JCOMDIS.2019.105938. 
bimbingan dan konseling mencakup empat bidang yakni, bimbingan pribadi ${ }^{28}$, bimbingan sosial ${ }^{29}$, bimbingan belajar ${ }^{30}$, dan bimbingan karier $^{31}$. Uraian ini menunjukkan bahwa siswalebih banyak memanfaatkan bimbingan dan konseling di bidang bimbingan belajar dan bimbingan sosial.

Jika ditinjau dari pola kedudukan Bimbingan dan Konseling dalam pendidikan, SMA X menempatkan kegiatan bimbingan dan konseling menjadi bagian dari pembinaan pribadi siswa (Student Personal Service), dalam kerangka mendukung kelancaran dan kesuksesan belajar. Ada kegiatan pembinaan siswa melalui berbagai cara ; Tapak suci, Hizbul wathan, Baitul arkom, dan kegiatan positif lainnya. Terkait dengan pola kedudukan bimbingan dan konseling ini, Hallen ${ }^{32}$ menjelaskan bahwa pola sebagaimana uraian tersebut menempatkan bimbingan dan konseling sebagai bagian dari kegiatan kesiswaan, yang memfokuskan pada pemberian konseling peserta didik, dengan model pendekatan remediatif-rehabilitatif.

Demikian pula, jika ditinjau dari pola-pola dasar pelaksanaannya, yakni asas pokok untuk mengatur penyebaran layanan bimbingan di sekolah terkait dengan bimbingan dan konseling islami, sekolahinimenggunakan pola generalis, yakni corak pendidikan berpengaruh pada kualitas dan kuantitas usaha belajar siswa, semua guru menyumbang pada pertumbuhan kepribadian Islami siswa, sehingga layanan bimbingan tersebar luas dengan melibatkan mayoritas tenaga pendidik. Para tenaga pengajar yang secara rutin berhubungan dengan siswa, memegang peranan penting dalam pola dasar ini. Ini menunjukkan bahwa mengatasi dan menyelesaikan persoalan siswa remaja melalui pendekatan religious juga harus melibatkan semua pihak dan mencakup learning by doing dimana siswa diajak untuk aktif dalam banyak kegiatan. Hal ini penting dilakukan selain membuat waktu mereka dapat digunakan pada hal yang positif juga mengajak siswa untuk ikut merasakan moral doing.

${ }^{28}$ Jung-Hye Lim and Yeongmi Ha, "Effectiveness of a Workplace Smoking Cessation Program Based on Self-Determination Theory Using Individual Counseling and Tailored Text Messaging: A Pilot Study," Asian Nursing Research 13, no. 1 (February 1, 2019): 53-60, https://doi.org/10.1016/J.ANR.2019.01.004.

${ }^{29}$ Nancy Brener and Zewditu Demissie, "Counseling, Psychological, and Social Services Staffing: Policies in U.S. School Districts," American Journal of Preventive Medicine 54, no. 6 (June 1, 2018): S215-19, https://doi.org/10.1016/J.AMEPRE.2018.01.031.

${ }^{30}$ Ecaterina Sarah Frăsineanu, "Counseling Learning. From Knowledge to Learning Methodology Choice," Procedia - Social and Behavioral Sciences 180 (May 5, 2015): 1599-1604, https://doi.org/10.1016/J.SBSPRO.2015.02.313.

${ }^{31}$ Francis Milot-Lapointe, Réginald Savard, and Yann Le Corff, "Intervention Components and Working Alliance as Predictors of Individual Career Counseling Effect on Career Decision-Making Difficulties," Journal of Vocational Behavior 107 (August 1, 2018): 15-24, https://doi.org/10.1016/J.JVB.2018.03.001.

${ }^{32}$ Hallen, Bimbingan Dan Konseling,. 


\section{Penutup}

Permasalahan utama yang dihadapi siswa siswi SMA X terkait dengan bidang belajar ini adalah kesulitan belajar. hal ini nampak jelas dilihat dari hasil capaian prestasi belajar, motivasi belajar rendah, masuk kelas menunggu perintah padahal bel telah berbunyi, sulit mengatur waktu, fenomena di kelas ketika proses belajar mengajar berlangsung, ada siswa di dalam kelas tidur, ada juga yang main game menggunakan HP, sering tidak masuk sekolah, sampai bolos dari sekolah. siswa muncul terkait dengan disiplin, moral, pembelajaran dan disiplin. Siswa juga mengalami masalah cemas terhadap masa depan. Pada umumnya anak anak yang bermasalah mereka berasal dari keluarga yang jarang berinteraksi dengan sesama anggota keluarga, orang tua sibuk, orang tua yang broken dan kurang kasih sayang dari orang tua. Selain itu, masalah siswa muncul dipengaruhi oleh penggunaan gadget dan pengaruh lingkungan. Model bimbingan konseling berbasis religiusitas yang diterapkan adalah mengajak siswa masuk ke masjid, pembiasaan melakukan kebaikan, member tauladan, membiat siswa nyaman dalam belajar dan berbaus dengan siswa di saat santai. 
Siti Bahiroh dan Fitri M. Suud : Model Bimbingan Konseling ... | 47

\section{Bibliografi}

Alavi, Masoumeh, Nazanin Boujarian, and Mohd Tajudin Ninggal. "The Challenges of High School Counselors in Work Place." Procedia - Social and Behavioral Sciences 46 (January 1, 2012): 4786-92. https://doi.org/10.1016/J.SBSPRO.2012.06.335.

Andriyani, Isnanita Noviya, Alef Theria Wasim, Mahli Zainuddin, and Fitriah M. Suud. "Gadgets Playing Behavior of Students In Indonesia." Humanities \& Social Sciences Reviews 8, no. 1 (2020): 264-71.

Bahiroh, Siti, Sekar Ayu Pratiwi, and Fitriah M. Suud. "Improving Student Happiness Through The Snowball Throwing Method In The Implementation of Student Conceling Groups of State Vocational Schools 2 Depok Yogyakarta." Journal of Critical Reviews 7, no. 5 (2020): 563-68. https://doi.org/doi: 10.31838/jcr.07.05.117.

Balobaid, Ameera, Alya Qari, and Hamad Al-Zaidan. "Genetic Counselors' Scope of Practice and Challenges in Genetic Counseling Services in Saudi Arabia." International Journal of Pediatrics and Adolescent Medicine 3, no. 1 (March 1, 2016): 1-6. https://doi.org/10.1016/J.IJPAM.2015.12.002.

Bashori, Khoiruddin. "Menyemai Perilaku Prososial Di Sekolah.” Sukma: Jurnal Pendidikan 1, no. 1 (2017): 57-92.

Bastaman, Hanna Djumhana. Integrasi Psikologi Dengan Islam Menuju Psikologi Islami. Yogyakarta: Pustaka Pelajar, 2005.

BISHOP, D. RUSSELL. "Religious Values as Cross-Cultural Issues in Counseling." Counseling and Values 36, no. 3 (April 1, 1992): 179-91. https://doi.org/10.1002/j.2161-007X.1992.tb00786.x.

Brener, Nancy, and Zewditu Demissie. "Counseling, Psychological, and Social Services Staffing: Policies in U.S. School Districts." American Journal of Preventive Medicine 54, no. 6 (June 1, 2018): S215-19. https://doi.org/10.1016/J.AMEPRE.2018.01.031.

Burov, O.Yu. Life-Long Learning: Individual Abilities versus Environment and Means, CEUR Workshop Proceedings, 2016. http:/ /lib.iitta.gov.ua/704844/.

Carroll-Alfano, Miriam A. "Education, Counseling, Support Groups, and Provider Knowledge of Total Laryngectomy: The Patient's Perspective." Journal of Communication Disorders 82 (November 1, 2019): 105938. https://doi.org/10.1016/J.JCOMDIS.2019.105938.

Dutta, Nabamita, Dipparna Jana, and Saibal Kar. "Does State-Level per Capita Income Affect Juvenile Delinquency? An Empirical Analysis for Indian States." Economic Modelling, July 2019. https://doi.org/10.1016/J.ECONMOD.2019.07.011. 
Frăsineanu, Ecaterina Sarah. "Counseling Learning. From Knowledge to Learning Methodology Choice." Procedia - Social and Behavioral Sciences 180 (May 5, 2015): 1599-1604. https://doi.org/10.1016/J.SBSPRO.2015.02.313.

Hallen. Bimbingan Dan Konseling, Jakarta: Ciputat Pers, 2002.

HOYT, KENNETH B. "GUIDANCE: A Constellation of Services." The Personnel and Guidance Journal 40, no. 8 (April 1, 1962): 690-97. https://doi.org/10.1002/j.2164-4918.1962.tb02185.x.

"What the School Has a Right to Expect of Its Counselor." The Personnel and Guidance Journal 40, no. 2 (October 1, 1961): 129-33. https://doi.org/10.1002/j.2164-4918.1961.tb02413.x.

Lim, Jung-Hye, and Yeongmi Ha. "Effectiveness of a Workplace Smoking Cessation Program Based on Self-Determination Theory Using Individual Counseling and Tailored Text Messaging: A Pilot Study." Asian Nursing Research 13, no. 1 (February 1, 2019): 53-60. https://doi.org/10.1016/J.ANR.2019.01.004.

Mappiare, Andi. Pengantar Konseling Dan Psikoterapi. Jakarta: Rajawali, 1992.

Milot-Lapointe, Francis, Réginald Savard, and Yann Le Corff. "Intervention Components and Working Alliance as Predictors of Individual Career Counseling Effect on Career Decision-Making Difficulties." Journal of Vocational Behavior 107 (August 1, 2018): 15-24. https://doi.org/10.1016/J.JVB.2018.03.001.

Musnamar, T. Dasar-Dasar Konseptual Bimbingan Dan Konseling Islami. Yogyakarta: UUI Pres, 1992.

Na'mah, Lutfia Uli, Nuri Zakiyyah, Ery Wahidatul Khasanah, Hermawan Hermawan, and Agung Setiawan. "Peningkatan Pengetahuan Melalui Sosialisasi Kesehatan Reproduksi Remaja Tentang Kenakalan Remaja." Proceeding of The URECOL, January 21, 2019, 263-66. http://repository.urecol.org/index.php/proceeding/article/view/349.

Suud, Fitriah M. "Kepemimpinan Transformasional Dan Implikasinya Pada Pembentukan Budaya Jujur Di Sekolah." Sukma: Jurnal Pendidikan 2, no. 2 (December 10, 2018): 261-86. https://doi.org/10.32533/02206.2018.

Suud, Fitriah M., Abd. Madjid, and Sutrisno. "The Study Of Educational Honesty Stages Implementation in an Indonesian School." Humanities \& Social Sciences Reviews 7, no. 4 (2019): 502-10. https://doi.org/https://doi.org/10.18510/hssr.2019.7467.

Syah, Muhibbin. Psikologi Pendidikan Dengan Pendekatan Baru. Bandung: Remaja Rosdakarya, 2016. 
Tudor, Keith, and Brigitte Viljoen. "Counselling and Psychotherapy of and in the South Pacific." Asia Pacific Journal of Counselling and Psychotherapy 9, no. 1 (January 2, 2018): 3-19. https://doi.org/10.1080/21507686.2017.1415944.

W.S.Winkel, and M.M. Sri Hastuti. Bimbingan Dan Konseling Di Institusi Pendidikan. Yogyakarta: Media Abadi, 2013.

Walgito, Bimo. Bimbingan Dan Penyuluban Di Sekolah. Yogyakarta, 1995.

Weng, Xue, Mao-Sheng Ran, and Wing Hong Chui. "Juvenile Delinquency in Chinese Adolescents: An Ecological Review of the Literature." Aggression and Violent Behavior 31 (November 1, 2016): 26-36. https://doi.org/10.1016/J.AVB.2016.06.016.

Wessel, Jason, Graham L. Bradley, and Michelle Hood. "Comparing Effects of Active and Passive Procrastination: A Field Study of Behavioral Delay." Personality and Individual Differences 139 (March 1, 2019): 152-57. https://doi.org/10.1016/J.PAID.2018.11.020. 
50 Islamic Counseling: Jurnal Bimbingan dan Konseling Islam, Vol. 4, No. 1, 2020 